\title{
Plasma and Brain Concentrations of Doxycycline after Single and Repeated Doses in Wild-Type and APP23 Mice ${ }^{\text {s }}$
}

\author{
๑ Jacopo Lucchetti, Claudia Fracasso, Claudia Balducci, Alice Passoni, ㄴ)Gianluigi Forloni, \\ (1) Mario Salmona, and 일orco Gobbi
}

\author{
Departments of Molecular Biochemistry and Pharmacology (J.L., C.F., M.S., M.G.), Neuroscience (C.B., G.F.), and Environmental \\ Health Science (A.P.), Instituto di Ricerche Farmacologiche Mario Negri IRCCS, Milan, Italy
}

Received July 20, 2018; accepted October 26, 2018

\begin{abstract}
Repurposing doxycycline for the treatment of amyloidosis has recently been put forward because of the antiaggregating and anti-inflammatory properties of the drug. Most of the investigations of the therapeutic potential of doxycycline for neurodegenerative amyloidosis, e.g., prion and Alzheimer disease (AD), have been carried out in mouse models, but surprisingly no data are available regarding the concentrations reached in the brain after systemic administration. We filled this gap by analyzing the pharmacokinetic profile of doxycycline in plasma and brain after single and repeated intraperitoneal injections of 10 and $100 \mathrm{mg} / \mathrm{kg}$, in wild-type mice and the APP23 mouse model of AD. The main outcomes of our study are: 1) Peak plasma concentrations ranged from 2 to $10 \mu \mathrm{g} / \mathrm{ml}$, superimposable to those in humans; 2 ) brain-to-plasma ratio was $\sim 0.2$, comparable
\end{abstract}

\section{Introduction}

Tetracyclines are a well known class of broad-spectrum antibiotics discovered in the late 1940s (Chopra and Roberts, 2001). More recent, extensive evidence suggests other interesting properties of these drugs, including antiapoptotic, anti-inflammatory, and antiaggregating activities (Griffin et al., 2010; Stoilova et al., 2013), which has prompted their repurposing to treat amyloidosis, a group of diseases caused by misfolding and abnormal aggregation of specific proteins that eventually accumulate as insoluble amyloid deposits (Chiti and Dobson, 2006). Doxycycline is a tetracycline derivative widely studied in these conditions.

Doxycycline disrupts transthyretin amyloid in vitro (Cardoso et al., 2003) and in vivo in animal models (Cardoso and Saraiva, 2006); in a phase 2 clinical trial, doxycycline plus tauroursodeoxycholic acid stabilized the disease in the majority of patients with hereditary transthyretin amyloidosis (Obici et al., 2012). In vitro and in vivo preclinical data also showed positive effects of doxycycline on amyloid light chain (AL) amyloidosis (Ward et al., 2011); this was followed by a report that the supplementation with doxycycline of standard chemotherapy in AL patients

https://doi.org/10.1124/jpet.118.252064.

S This article has supplemental material available at dmd.aspetjournals.org. to the cerebrospinal fluid/serum ratios in humans; 3) brain $\mathrm{C}_{\max }$ 4-6 hours after a single dose was $\sim 0.5(10 \mathrm{mg} / \mathrm{kg})$ and $\sim 5 \mu \mathrm{M}$ (100 mg/kg). Notably, these concentrations are lower than those required for the drug's antiaggregating properties as observed in cell-free studies, suggesting that other features underlie the positive cognitive effects in AD mice; 4) elimination half-life was shorter than in humans (3-6 vs. 15-30 hours), therefore no significant accumulation was observed in mouse brain following repeated treatments; and 5) there were no differences between doxycycline concentrations in brain areas of age-matched wildtype and APP23 mice. These data are useful for planning preclinical studies with translational validity, and to identify more reliably the mechanism(s) of action underlying the central in vivo effects of doxycycline.

ABBREVIATIONS: AUC, area under the curve; BBB, blood-brain-barrier; CJD, Creutzfeldt-Jakob disease; $\mathrm{C}_{\text {max }}$, peak concentration; $\mathrm{HCOOH}$, formic acid; HPLC, high-performance liquid chromatography; IS, internal standard; MS/MS, tandem mass spectrometry; PK, pharmacokinetic(s); $\mathrm{t}_{1 / 2}$, elimination half-life; WT, wild type.

reduced early cardiac mortality (Wechalekar and Whelan, 2017). Doxycycline also inhibits $\beta 2$-microglobulin $(\beta 2 \mathrm{M})$ fibrillogenesis (Giorgetti et al., 2011), prompting the proposal of "off-label" treatment of a severe form of dialysis-related $\beta 2 \mathrm{M}$ amyloidosis in three patients who displayed a significant reduction in articular pain (Montagna et al., 2013). The use of doxycycline as an orphan drug for the treatment of hereditary amyloid polyneuropathy caused by $\beta 2 \mathrm{M}$ was recently approved by the European Committee for Orphan Medicinal Products (http:// www.emea.europa.eu/docs/en_GB/document_library/Orphan_designation/2012/05/WC500127736.pdf). Doxycycline might also have therapeutic potential for neurodegenerative amyloidosis, such as in prion diseases and Alzheimer disease (AD), according to in vitro and animal data (Forloni et al., 2001, 2002; De Luigi et al., 2008; Diomede et al., 2010). A recent phase 2 study in Creutzfeldt-Jakob disease (CJD) patients at an early stage demonstrated the superiority of doxycycline over control (Varges et al., 2017), contrasting with the negative results of an earlier study (Haik et al., 2014) carried out however in CJD patients at a very late stage. Contrasting results were also obtained in clinical trials with doxycycline in $\mathrm{AD}$ patients (Loeb et al., 2004; Molloy et al., 2013). A preventive clinical trial in patients with fatal familial insomnia, a genetic prion disease, is currently ongoing (Forloni et al., 2015). 
Different variables affect the in vivo activity of doxycycline for treating amyloidosis, including the stage of the disease when treatment starts, and whether the treatment regimen can achieve adequate drug concentrations at the active site (e.g., in the brain for neurodegenerative amyloidosis).

Many of the main pharmacokinetic (PK) features of doxycycline in humans have already been investigated in detail (Cunha et al., 1982; Saivin and Houin, 1988): At the usual oral doses of 100-200 mg/day, it is absorbed rapidly and almost completely, with peak serum concentrations from 1.7 to $5.9 \mu \mathrm{g} / \mathrm{ml}$ 2-3 hours after dosing, and elimination half-life of 15-30 hours (Saivin and Houin, 1988; Binh et al., 2009; Montagna et al., 2013). After long-term administration of $100 \mathrm{mg} /$ day, concentrations at steady-state reach 0.7-1.5 $\mu \mathrm{g} / \mathrm{ml}$ (Binh et al., 2009; Montagna et al., 2013). Plasma protein binding of doxycycline is 80\%-90\% (Cunha et al., 1982; Saivin and Houin, 1988) and there is no significant metabolism (Yim et al., 1985; Saivin and Houin, 1988). Because of its lipophilicity-much higher than that of tetracycline-doxycycline easily penetrates and distributes within body tissues. However, very few data are available on its ability to cross the blood-brain barrier (BBB): In patients with neurosyphilis (Yim et al., 1985) or suspected tick-borne neuroborreliosis (Dotevall and Hagberg, 1989), cerebrospinal fluid concentrations were $15 \%-25 \%$ of serum levels. Brain concentrations of doxycycline were also measured in autopsy samples from late-stage CJD patients given $100 \mathrm{mg}$ daily (Haik et al., 2014): The drug crossed the BBB and persisted in the brain for days after the end of treatment, possibly because of its ability to bind the prion protein aggregates present in the brain of CJD patients.

A more detailed analysis of BBB passage can be obtained in animal models, particularly rodents, which also offer the possibility of correlating a pharmacological effect (e.g., on amyloid load or neuroprotection) with the actual brain concentrations. When planning treatment schedules in animals, one must also take into account that the drug's PK profile varies as a function of body weight (Boxenbaum, 1982).

Very few reports describe the PK of doxycycline in rodents. The half-time of elimination from serum is 3-4 hours (Schach won Wittenau et al., 1972; Bocker et al., 1981), i.e., significantly faster than in humans; the brain-to-plasma concentration ratio was 0.31 at a single time point (4 hours) after intravenous injection of $25 \mathrm{mg} / \mathrm{kg}$ in rats (Colovic and Caccia, 2003). To our knowledge, no data are available on BBB passage in mice.

Given the paucity of published data and the importance of this information for planning preclinical studies with translational validity, we carried out ad hoc PK studies in mice, measuring plasma and brain levels of doxycycline after single and repeated intraperitoneal injections. We also did a single-dose study to measure plasma and brain levels of doxycycline in APP23 mice, a transgenic model of $\mathrm{AD}$. The analytical method, employing highperformance liquid chromatography (HPLC)-tandem mass spectrometry (MS/MS), was developed and validated according to accepted guidelines.

\section{Materials and Methods}

\section{Mice}

Three groups of mice were used: 1) 7-week-old, male C57Bl/6 CRI mice (Charles River Laboratories Italia, Calco, Italy), 2) 20-month-old, female and male APP23 transgenic (Tg) mice, and 3) sex- and agematched wild-type (WT) female and male littermates. Mice were housed three to four per cage at constant room temperature $\left(21 \pm 1^{\circ} \mathrm{C}\right)$ and relative humidity (60\%) with a 12-hour light cycle (lights on 7:00 AM to 7:00 PM) with food and water ad libitum (Global Diet 2018S; Envigo, Somerset, NJ). Procedures involving animals were conducted at the Instituto di Ricerche Farmacologiche "Mario Negri" (IRCCS), which adheres to the principles set out in the following laws, regulations, and policies governing the care and use of laboratory animals: Italian Governing Law (D.lgs 26/2014; Authorization n.19/2008-A issued March 6, 2008 by Ministry of Health); Mario Negri Institutional Regulations and Policies providing internal authorization for persons conducting animal experiments which includes ad hoc members for ethical issues (authorization code 1/05-D) (Quality Management System CertificateUNI EN ISO 9001:2008-Reg. N ${ }^{\circ}$ 6121). The NIH Guide for the Care and Use of Laboratory Animals (2011 edition), and EU directives and guidelines (EEC Council Directive 2010/63/UE). The Statement of Compliance (Assurance) with the Public Health Service (PHS) Policy on Human Care and Use of Laboratory Animals has been recently reviewed (9/9/2014) and expired on September 30, 2019 (Animal Welfare Assurance no. A5023-01).

\section{Drug Treatments}

Doxycycline hyclate $\mathrm{HCl}$ (MilliporeSigma, St. Louis, MO) was dissolved in sterile $0.9 \%$ saline at 10 and $100 \mathrm{mg} / \mathrm{ml}$ (free base) and injected intraperitoneally in volumes of $10 \mathrm{ml} / \mathrm{kg}$ to have final doses of 10 and $100 \mathrm{mg} / \mathrm{kg}$.

Single Treatment in 7-Week-Old Male C57B1/6 Mice. Mice weighing $24.4 \pm 1.5 \mathrm{~g}$ were treated with 10 and $100 \mathrm{mg} / \mathrm{kg}$ (36 mice for each dose) and killed by decapitation at 0.5, 1, 2 4, 6, 8, 10, 20, and 24 hours after the injection (4/time point/dose).

Repeated Treatment in 7-Week-Old Male C57Bl/6 Mice. Mice weighing $25.3 \pm 1.3 \mathrm{~g}$ were given 10 and $100 \mathrm{mg} / \mathrm{kg}$ doxycycline (24 mice/dose) once a day (9:00 AM) for four injections (12) or twice a day (17:00 and 9:00) for eight injections (12). Mice were killed just before, or 2 and 6 hours after, the last injection (4 mice/time point).

Single Treatment in 20-Month-Old Male and Female WT Mice. Mice weighing $39.8 \pm 10.8 \mathrm{~g}$ were treated with $100 \mathrm{mg} / \mathrm{kg}$ and killed by decapitation at $2,6,8,10,16$, and 24 hours after the injection ( $n=3-6 /$ time point).

Repeated Treatments in 20-Month-Old Male and Female APP23 and WT Mice. WT and APP23 mice weighing $33.0 \pm 9.8 \mathrm{~g}$ were given $100 \mathrm{mg} / \mathrm{kg}$ (three for group) once a day for four consecutive days, and killed by decapitation 24 hours after the last injection.

Blood samples were transferred to heparinized tubes and kept in ice until centrifugation at $2000 \mathrm{~g}$ for 15 minutes $\left(4^{\circ} \mathrm{C}\right)$, to obtain plasma that was stored at $-80^{\circ} \mathrm{C}$ until HPLC-MS/MS analysis. Immediately after death brain tissues were removed, dissected into two halves, and kept on dry ice before storage at $-80^{\circ} \mathrm{C}$. The day of analysis, the brain tissues and dissected cerebral areas were homogenized in phosphate buffer $0.01 \mathrm{M} \mathrm{pH} 7.4$ (1 $\mathrm{g}$ in $6 \mathrm{ml})$ with an Ultra Turrax T10 basic (IKAWerke GmbH \& Co., Staufen, DE) and processed as described below.

\section{Doxycycline Concentrations in Plasma and Brain}

The analytical method and procedures for its validation are described fully in the Supplemental Material. Briefly, after addition of internal standard (IS, demeclocycline), $50 \mu \mathrm{l}$ of plasma or $200 \mu \mathrm{l}$ brain homogenate were purified by protein precipitation with five volumes of cold acetonitrile (with $0.1 \%$ of formic acid), and centrifuged. The supernatants were evaporated under a nitrogen flow, and the residues resuspended in $0.1 \% \mathrm{HCOOH}$ in water/acetonitrile $(98 / 2$, v/v) and injected into the HPLC-MS/MS. Separation was done on a Kinetex EVO C18 column with HCOOH $0.1 \%$ in water (mobile phase A, MP-A) and acetonitrile (mobile phase B, MP-B); elution started with $98 \%$ of MP-A held for 2 minutes followed by a 10-minute nonlinear gradient (curve 8) to $98 \%$ of MP-B. Doxycycline and the IS were acquired in positive multiple reaction mode monitoring the quantitative ion transitions mass-to-charge ratio $(\mathrm{m} / \mathrm{z}) 445.1 \rightarrow \mathrm{m} / \mathrm{z} 428.1$ (collision 

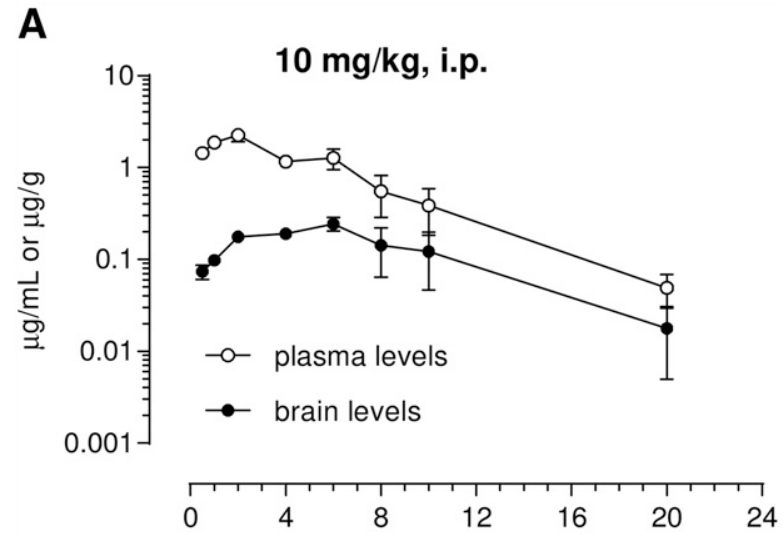

time (h)

B

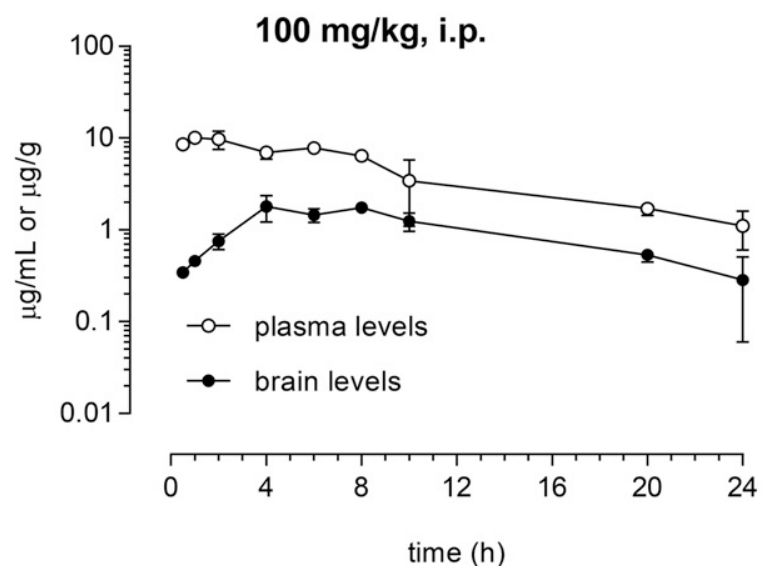

\begin{tabular}{ccc}
\hline PK parameters & Plasma & Brain \\
\hline $\mathrm{C}_{\max }(\mu \mathrm{g} / \mathrm{mL}$ or $\mu \mathrm{g} / \mathrm{g})$ & $2.26 \pm 0.34$ & $0.22 \pm 0.02$ \\
$\mathrm{t}_{\max }(\mathrm{h})$ & 2 & 6 \\
$\mathrm{t}_{1 / 2}(\mathrm{~h})$ & 3.2 & 3.9 \\
$\mathrm{AUC}_{0-2 \mathrm{~h}}\left(\mu \mathrm{g}^{*} \mathrm{~h} / \mathrm{mL}\right.$ or $\left.\mu \mathrm{g}^{*} \mathrm{~h} / \mathrm{g}\right)$ & 14.02 & 2.35 \\
$\mathrm{AUC}_{0-\mathrm{inf}}\left(\mu \mathrm{g}^{*} \mathrm{~h} / \mathrm{mL}\right.$ or $\left.\mu \mathrm{g}^{*} \mathrm{~h} / \mathrm{g}\right)$ & 14.22 & 2.45 \\
$\mathrm{Vz} / \mathrm{F}(\mathrm{mL} / \mathrm{kg})$ & 3283 & \\
$\mathrm{Cl} / \mathrm{F}\left(\mathrm{mL} / \mathrm{h}^{*} \mathrm{~kg}\right)$ & 703 & \\
\hline
\end{tabular}

\begin{tabular}{ccc}
\hline PK parameters & Plasma & Brain \\
\hline $\mathrm{C}_{\max }(\mu \mathrm{g} / \mathrm{mL}$ or $\mu \mathrm{g} / \mathrm{g})$ & $10.04 \pm 0.91$ & $1.79 \pm 0.57$ \\
$\mathrm{t}_{\max }(\mathrm{h})$ & 1 & 4 \\
$\mathrm{t}_{1 / 2}(\mathrm{~h})$ & 6.5 & 6.5 \\
$\mathrm{AUC}_{0-24 \mathrm{~h}}\left(\mu \mathrm{g}^{*} \mathrm{~h} / \mathrm{mL}\right.$ or $\left.\mu \mathrm{g}^{*} \mathrm{~h} / \mathrm{g}\right)$ & 110.22 & 23.41 \\
$\mathrm{AUC}_{0-\text {-inf }}\left(\mu \mathrm{g}^{*} \mathrm{~h} / \mathrm{mL}\right.$ or $\left.\mu \mathrm{g}^{*} \mathrm{~h} / \mathrm{g}\right)$ & 120.55 & 26.08 \\
$\mathrm{Vz} / \mathrm{F}(\mathrm{mL} / \mathrm{kg})$ & 7785 & \\
$\mathrm{Cl} / \mathrm{F}\left(\mathrm{mL} / \mathrm{h}^{*} \mathrm{~kg}\right)$ & 830 & \\
\hline
\end{tabular}

Fig. 1. Time course of doxycycline concentrations in plasma (white circles) and brain (black circles) of 7-week-old male WT mice injected with (A) 10 or (B) $100 \mathrm{mg} / \mathrm{kg}$, i.p. Each point is the mean \pm S.D. of four mice. Tables report the corresponding PK parameters calculated with PKSolver.

energy $20 \mathrm{eV}$ ) and $\mathrm{m} / \mathrm{z} 465.1 \rightarrow \mathrm{m} / \mathrm{z} 448.1$ (collision energy $15 \mathrm{eV}$ ), respectively.

Plasma and brain samples of treated mice were analyzed in parallel with quality control samples (two replicates at three concentrations) and with freshly prepared calibration curves linear in the range 0.1-10 $\mu \mathrm{g} / \mathrm{ml}$ for plasma and 60-6000 $\mathrm{ng} / \mathrm{g}$ for brain.

The GraphPad Prism program (GraphPad Software, Inc. La Jolla, CA), was used for plotting the calibration curves and for quantifying the unknown concentrations of doxycycline in plasma and brain. The same software was used for statistical analysis and graphics. Plasma and brain PK profiles were analyzed using a noncompartmental model for extravascular administration to obtain the main PK parameters. The peak concentration $\left(\mathrm{C}_{\max }\right)$ and the time taken to reach it $\left(\mathrm{T}_{\max }\right)$ were taken directly from the data; elimination half-life $\left(t_{1 / 2}\right)$, area under the curve from 0 to the last time point $\left(\mathrm{AUC}_{0-\mathrm{t}}\right)$ and from 0 to infinity $\left(\mathrm{AUC}_{0-\mathrm{inf}}\right)$, apparent volume of distribution $(\mathrm{V} / \mathrm{F})$, and apparent clearance $(\mathrm{Cl} / \mathrm{F})$ were obtained with PKSolver, a freely available menu-driven add-in program for Microsoft Excel (Zhang et al., 2010).

\section{Identification and Analysis of Metabolites in Plasma and Brain}

In vivo formation of doxycycline metabolites was investigated using a high-resolution mass spectrometer (Q Exactive Orbitrap; Thermo Fisher Scientific, Waltham, MA) coupled with a liquid chromatographic system (1200 series; Agilent Technologies, Santa Clara, CA). Extraction procedure from biologic matrices and HPLC-MS/MS analysis is described in the Supplemental Material.

\section{Results}

\section{HPLC-MS/MS Method Validation}

We developed an HPLC-MS/MS method and validated it following EMA guidelines (http://www.ema.europa.eu/docs/en_GB/ document_library/Scientific_guideline/2011/08/WC500109686.pdf).

Analysis of plasma and brain homogenates spiked with different amounts of doxycycline (respectively, 0.1-10 $\mu \mathrm{g} / \mathrm{ml}$ and $60-6000 \mathrm{ng} / \mathrm{g}$ ) allowed evaluation of the linearity of response and limits of quantifications $(0.1 \mu \mathrm{g} / \mathrm{ml}$ and $60 \mathrm{ng} /$ $\mathrm{g}$ ), the selectivity (i.e., the ability of the method to distinguish doxycycline and the IS from other components of the biologic matrices), the recovery and matrix effects, accuracy and precision, carryover, and analyte stability in the different experimental conditions. All these validation data are detailed in the Supplemental Material.

\section{Pharmacokinetic Studies}

Single Treatment in 7-Week-Old C57B1/6 Mice. Figure 1 shows the pharmacokinetic profile of doxycycline in plasma and brain of male $\mathrm{C} 57 \mathrm{Bl} / 6$ mice, at different times after a single i.p. dose of 10 or $100 \mathrm{mg} / \mathrm{kg}$. After the lowest dose (Fig. $1 \mathrm{~A})$, plasma concentration $\left(\mathrm{C}_{\max }\right)$ of $2.26 \pm 0.34 \mu \mathrm{g} / \mathrm{ml}$ (mean \pm S.D., four mice) peaked at 2 hours. The terminal phase had a half-life of 3.2 hours; concentrations were not detectable at 
24 hours. $\mathrm{AUC}_{0-20 \mathrm{~h}}$ and $\mathrm{AUC}_{0-\mathrm{inf}}$ were similar. The analysis of brain tissues (Fig. 1A) indicated a rapid distribution of doxycycline, with quantifiable levels 30 minutes after the dose; the $\mathrm{C}_{\max }(0.22 \pm 0.04 \mu \mathrm{g} / \mathrm{g})$ was reached at 6 hours after the treatment. Brain doxycycline declined with a $t_{1 / 2}$ of 3.9 hours. $\mathrm{AUC}_{0-24}$ hours and $\mathrm{AUC}_{0-\text { inf }}$ were also closed. The ratio

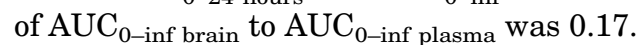

After the highest dose plasma $\mathrm{C}_{\max }$ was reached at 1 hour (Fig. $1 B$ ), the terminal half-life calculated on the last three points was 6.5 hours. In the brain, $\mathrm{C}_{\text {max }}$ was reached after 4 hours and concentrations declined then with $\mathrm{t}_{1 / 2}$ of 6.5 hours. At this dose, the ratio of $\mathrm{AUC}_{0-\text { inf brain }}$ to $\mathrm{AUC}_{0-\text { inf plasma was }} 0.22$. The ratio of $\mathrm{AUC}_{0-\text { inf }}(100 \mathrm{mg} / \mathrm{kg})$ to $\mathrm{AUC}_{0-\text { inf }}(10 \mathrm{mg} / \mathrm{kg})$ was 8.5 in plasma and 10.6 in brain tissue, indicating dose-proportionality.

Repeated Treatment in 7-Week-Old C57Bl/6 Mice. Data after a single intraperitoneal injection were used to simulate the expected PK profiles after repeated doses of 10 and $100 \mathrm{mg} / \mathrm{kg}$ doxycycline, once or twice a day.
These simulations are shown in Fig. $2(10 \mathrm{mg} / \mathrm{kg})$ and Fig. 3 $(100 \mathrm{mg} / \mathrm{kg})$ for brain and in Supplemental Figures 4 and 5 for plasma, with their variability (as S.D.). We considered these simulations useful 1) to visually show that the fast elimination of doxycycline does not allow significant accumulation of the drug during repeated treatment, with the partial exception of the higher dose twice a day, and 2) to verify experimentally that the concentrations after repeated administrations are as expected, thus excluding possible changes in the PK profile during chronic treatment (e.g., in absorption or elimination mechanisms).

Figures 2 and 3 show that brain doxycycline concentrations measured just before, or 2 and 6 hours after, the last of four once-a-day injections or eight twice-a-day injections, are mostly within the expected values, and not significantly different from the concentrations after single injections, although we noticed a slight accumulation after eight twice-a-day injections with both doses. Plasma doxycycline
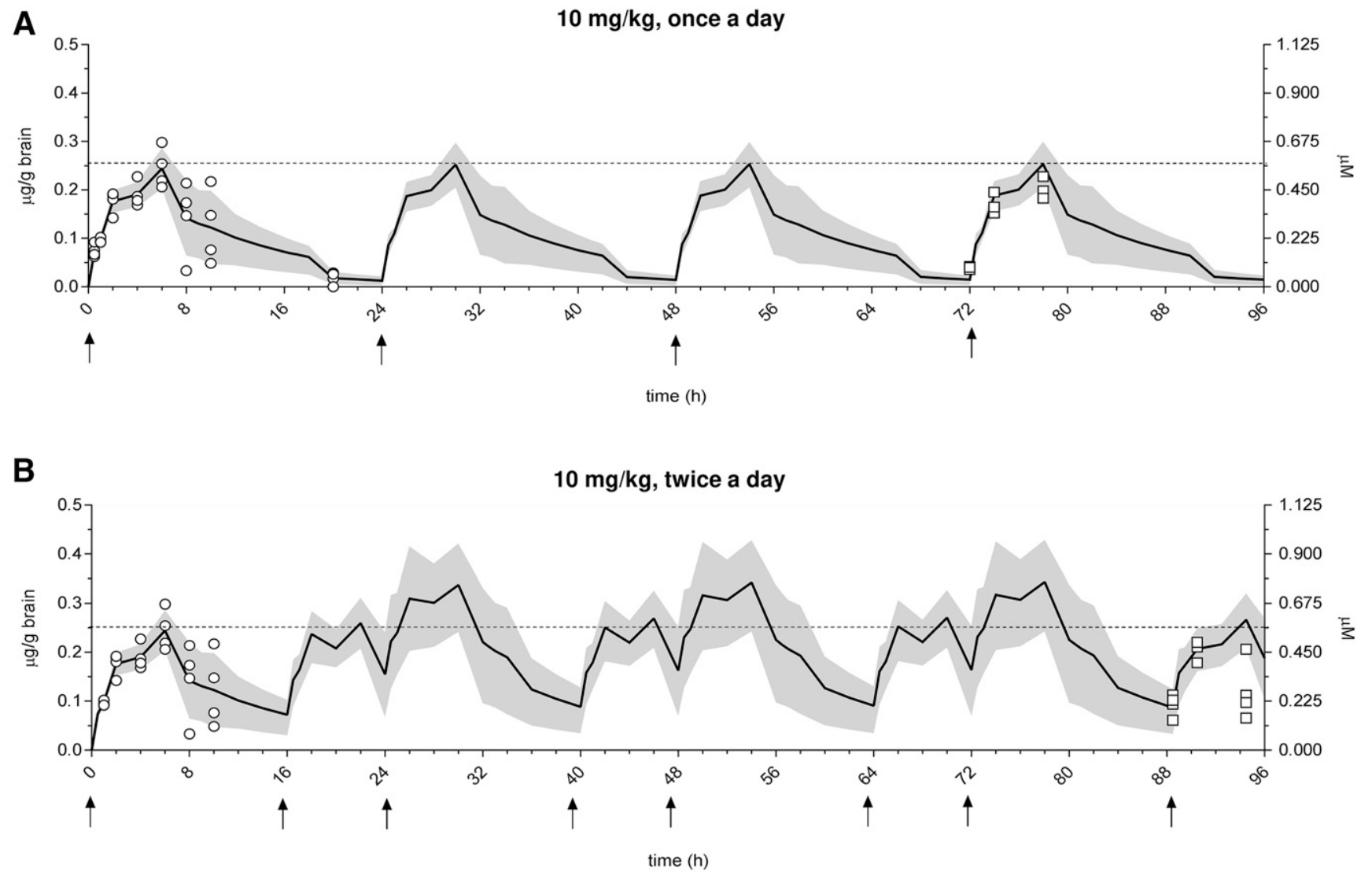

\begin{tabular}{|c|c|c|c|c|}
\hline \multirow{2}{*}{$\begin{array}{c}\text { Time after last dose } \\
\text { (h) }\end{array}$} & Single dose & \multicolumn{2}{|c|}{$\begin{array}{c}\text { Multiple doses, once a day } \\
\text { (4 injections) }\end{array}$} & \multicolumn{2}{c|}{$\begin{array}{c}\text { Multiple doses, twice a day } \\
(8 \text { injections) }\end{array}$} & $P$ value & $\mu g / g(m e a n \pm S D)$ \\
\cline { 2 - 5 } & $\mu g / g($ mean $\pm S D)$ & $\mu g / g($ mean $\pm S D)$ & 0.6857 & $0.203 \pm 0.022$ \\
\hline 2 & $0.176 \pm 0.023$ & $0.141 \pm 0.062$ & 0.2286 & $0.120 \pm 0.061$ \\
\hline 6 & $0.244 \pm 0.041$ & $0.203 \pm 0.023$ & 0.0571 \\
\hline
\end{tabular}

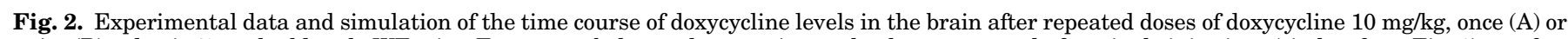

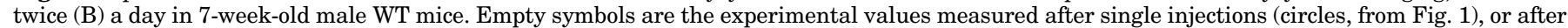

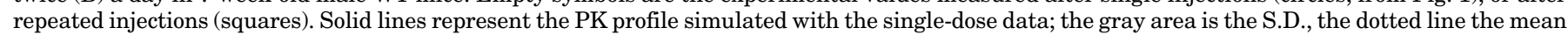

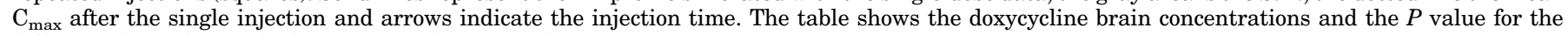
difference from the single dose (Mann Whitney test). 

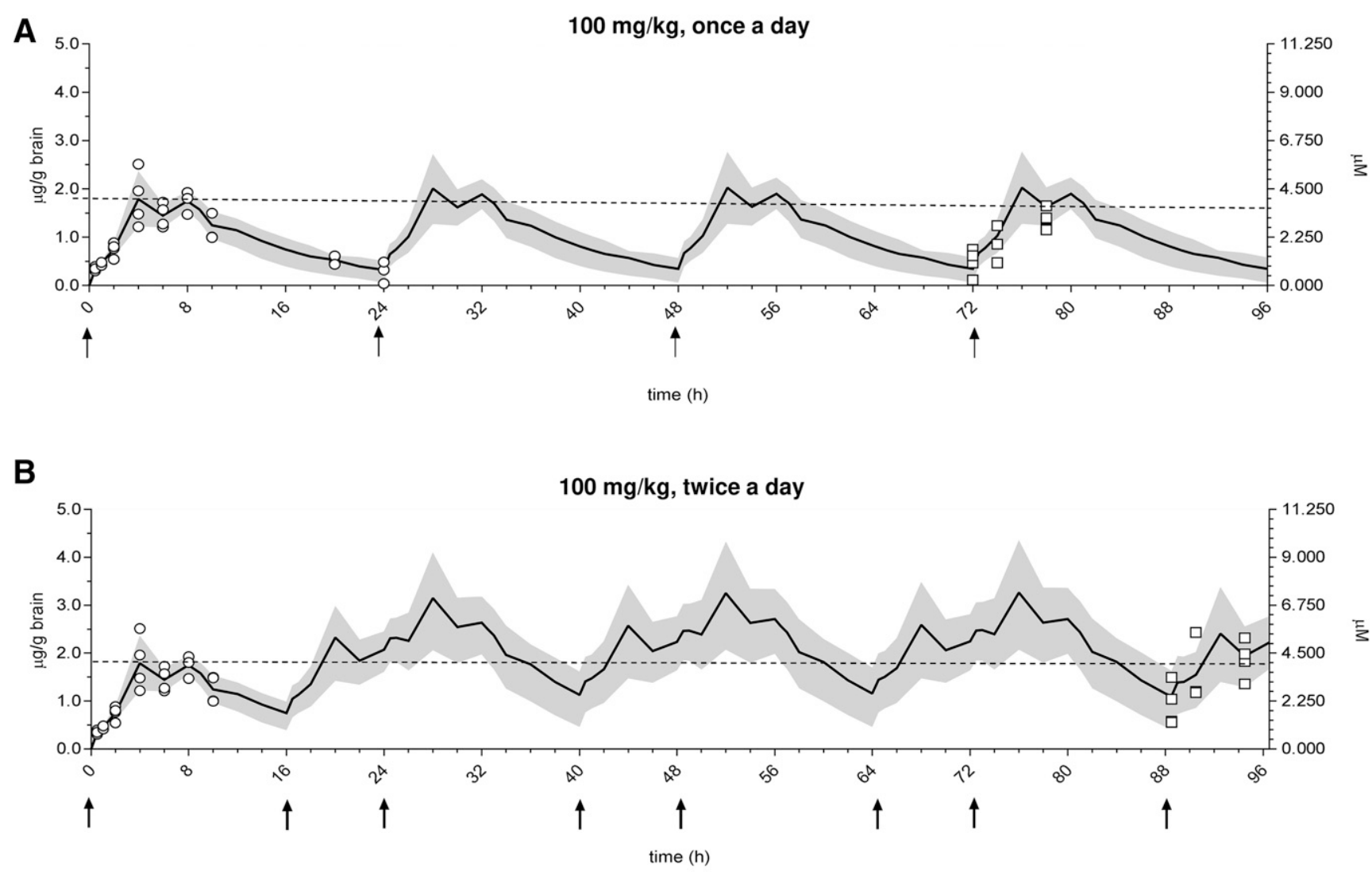

\begin{tabular}{|c|c|c|c|c|c|}
\hline \multirow{2}{*}{$\begin{array}{c}\text { Time after last dose } \\
\text { (h) }\end{array}$} & Single dose & \multicolumn{2}{|c|}{$\begin{array}{c}\text { Multiple doses, once a day } \\
(4 \text { injections) }\end{array}$} & \multicolumn{3}{|c|}{$\begin{array}{c}\text { Multiple doses, twice a day } \\
(8 \text { injections) }\end{array}$} \\
\cline { 2 - 7 } & $\mu g / g($ mean $\pm S D)$ & $\mu g / g$ (mean $\pm S D)$ & $P$ value & $\mu g / g(m e a n \pm S D)$ & $P$ value \\
\hline 2 & $0.750 \pm 0.145$ & $0.857 \pm 0.383$ & 0.8571 & $1.604 \pm 0.719$ & 0.0571 \\
\hline 6 & $1.447 \pm 0.244$ & $1.396 \pm 0.204$ & 0.8857 & $1.874 \pm 0.400$ & 0.1143 \\
\hline
\end{tabular}

Fig. 3. Experimental data and simulation of the time course of doxycycline levels in the brain after repeated doses of doxycycline $100 \mathrm{mg} / \mathrm{kg}$, once (A) or twice (B) a day in 7-week-old male WT mice. Empty symbols are the experimental values measured after single injections (circles, from Fig. 1), or after repeated injections (squares). Solid lines represent the PK profile simulated with the single-dose data; the gray area is the S.D., the dotted line the mean $\mathrm{C}_{\max }$ after the single injection and arrows indicate the injection time. The table shows the doxycycline brain concentrations and the $P$ value for the difference from the single dose (Mann Whitney test).

concentrations after repeated treatment were mostly in line with expected values (Supplemental Figures 4 and 5).

\section{Single Treatment in 20-Month-Old C57BI/6 Mice}

Figure 4 shows the PK profile of doxycycline in plasma and brain of 20-month-old $\mathrm{C} 57 \mathrm{Bl} / 6$ mice at different times after a single i.p. dose of $100 \mathrm{mg} / \mathrm{kg}$. The aim was to gain PK information for the best design of studies in age-matched APP23 mice; thus, this analysis included both male $(n=12)$ and female $(n=10)$ mice, comparably distributed at the different time points. No clear-cut differences were noted (data not shown), so the values for the two genders were combined.

The time courses of plasma and brain levels in these 20-month-old mice were superimposable on those of younger mice, except at the longest time points (Fig. 4). Analysis of the last four points gave $t_{1 / 2}$ of 11.1 (plasma) and 15.5 hours (brain), about double those in younger mice. The absolute $\mathrm{Cl} / \mathrm{F}$ were comparable, whereas the absolute apparent volume of distribution during terminal phase after nonintravenous injection $(\mathrm{Vz} / \mathrm{F})$ was higher in older mice (332 $\mathrm{ml}$ vs. $180 \mathrm{ml}$ in younger mice). The brain-toplasma ratio ( $\mathrm{AUC}_{0-\text { inf brain }} / \mathrm{AUC}_{0-\text { inf plasma }}$ ) was about $20 \%$ for both ages.

Repeated Treatment in 20-Month-Old APP23 Mice. On the basis of the data in 20-month-old WT mice, doxycycline levels were measured 24 hours after the fourth i.p. injection (1/day) of $100 \mathrm{mg} / \mathrm{kg}$ in three APP23 mice (two females and one male) and three sex- and age-matched WT mice, in several brains areas: cortex, hippocampus, cerebellum, striatum, and the "rest of the brain." Doxycycline levels were measured at this time point on the basis of the PK profile observed in age-matched mice treated once (Fig. 4); in fact, distribution equilibrium is more probably achieved at the end of the dosing interval and, therefore, a trough value allows a better estimation of the degree of accumulation than $\mathrm{C}_{\text {max }}$ (Rowland and Tozer, 2011). Moreover, mice were treated with the highest doxycycline dose $(100 \mathrm{mg} / \mathrm{kg})$ 
A

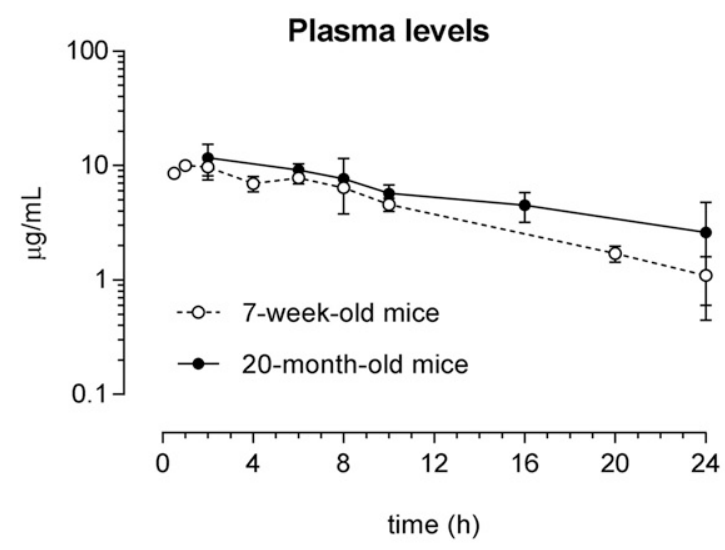

\begin{tabular}{ccc}
\hline Plasma PK parameters & $\begin{array}{c}\text { 7-week-old } \\
\text { mice }\end{array}$ & $\begin{array}{c}\text { 20-month-old } \\
\text { mice }\end{array}$ \\
\hline Weight $(\mathrm{g})$ & $24.4 \pm 1.5$ & $39.8 \pm 10.8$ \\
mean dose $(\mathrm{mg} /$ mice $)$ & 2.44 & 3.98 \\
$\mathrm{k}_{\mathrm{el}}(1 / \mathrm{h})$ & 0.107 & 0.063 \\
$\mathrm{t}_{1 / 2}(\mathrm{~h})$ & 6.5 & 11.1 \\
$\mathrm{AUC}_{0-24 \mathrm{~h}}\left(\mu \mathrm{g}^{*} \mathrm{~h} / \mathrm{mL}\right)$ & 110.22 & 142.8 \\
$\mathrm{AUC}_{0 \text {-inf }}\left(\mu \mathrm{g}^{*} \mathrm{~h} / \mathrm{mL}\right)$ & 120.55 & 184.4 \\
$\mathrm{Vz} / \mathrm{F}(\mathrm{mL})$ & 190.0 & 344.5 \\
weight-adjusted $\mathrm{Vz} / \mathrm{F}(\mathrm{mL} / \mathrm{kg})_{\mathrm{Cl} / \mathrm{F}(\mathrm{mL} / \mathrm{h})}$ & 7785 & 8655 \\
\hline weight-adjusted $\mathrm{Cl} / \mathrm{F}\left(\mathrm{mL} / \mathrm{h}^{*} \mathrm{~kg}\right)$ & 20.3 & 21.6 \\
\hline
\end{tabular}

B

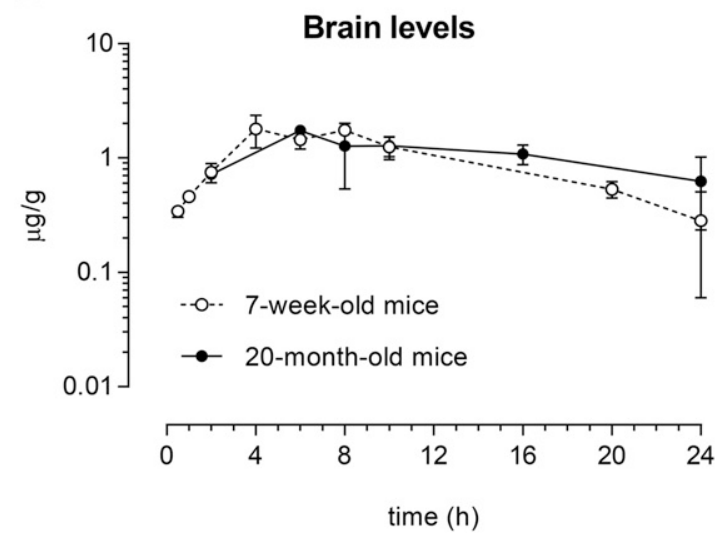

\begin{tabular}{|c|c|c|}
\hline Brain PK parameters & $\begin{array}{l}\text { 7-week-old } \\
\text { mice }\end{array}$ & $\begin{array}{l}\text { 20-month-old } \\
\text { mice }\end{array}$ \\
\hline Weight (g) & $24.4 \pm 1.5$ & $39.8 \pm 10.8$ \\
\hline mean dose (mg/mice) & 2.44 & 3.98 \\
\hline $\mathrm{k}_{\mathrm{el}}(1 / \mathrm{h})$ & 0.106 & 0.045 \\
\hline$t_{1 / 2}(h)$ & 6.5 & 15.4 \\
\hline$A \cup C_{0-24 h}\left(\mu g^{*} h / g\right)$ & 23.41 & 25.12 \\
\hline $\mathrm{AUC}_{0 \text {-inf }}\left(\mu \mathrm{g}^{\star} \mathrm{h} / \mathrm{g}\right)$ & 26.08 & 38.96 \\
\hline Brain $A \cup C_{0 \text {-inf }} /$ Plasma $\mathrm{AUC}_{0 \text {-inf }}$ & 0.22 & 0.21 \\
\hline
\end{tabular}

Fig. 4. Time course of doxycycline concentrations in (A) plasma and (B) brain measured in 20-month-old WT mice (black circles and solid lines) injected once with $100 \mathrm{mg} / \mathrm{kg}$, i.p. Each point is the mean \pm S.D. of three to six mice (both males and females). Tables report the corresponding PK parameters calculated with PKSolver. For comparison, the time course of doxycycline concentrations (white circles and dotted line), are reported with the corresponding PK parameters in 7-week-old male WT mice (from Fig. 1).

to have clearly measurable levels after 24 hours. Since preliminary studies in old WT mice showed some toxicity at this dose twice a day, we decided to treat APP23 mice once a day.

Brain levels of doxycycline were similar in WT and APP23 mice in all the regions considered (Table 1).

Identification and Analysis of In Vivo Doxycycline Metabolite. Since previous data suggested minimal metabolism of doxycycline (Bocker, 1983), initial analyses were carried out in a pool of plasma and brain samples obtained from the young WT mice chronically treated with the highest dose of doxycycline. $N$-demethylated doxycycline was the only metabolite identified in plasma (Supplemental Figure 6), whereas no metabolites were found in the brain samples. Subsequent semiquantitative analysis in all the plasma samples of the mice treated with $100 \mathrm{mg} / \mathrm{kg}$ doxycycline (all time points after single or repeated doses, in both young and old WT mice) showed that $N$-demethylated metabolite never exceed $5 \%$ of the parent drug (Supplemental Figure 7) (more details can be found in the Supplemental Material).

\section{Discussion}

Preclinical studies are often limited by inadequate evaluation of whether the drug dose actually achieves plasma and/or tissue (e.g., brain) concentrations with translational validity (meaning, that result in a similar exposure), and are

\section{TABLE 1}

Doxycycline levels in cortex (CTX), hippocampus (HIPP), cerebellum (CB), striatum (STR), and in the "rest of the brain" (ROB) of WT and APP23 mice 24 hours after the last of four daily intraperitoneal injections (mean \pm S.D. of three mice; two females and one male per group)

Two-way analysis of variance indicated no significant overall difference between WT and APP23 mice and multiple comparison test indicated no significant differences for the single brain areas.

\begin{tabular}{lcc}
\hline Brain Area & WT Mice & APP23 Mice \\
\hline & $\mu g / g$ & $\mu g / g$ \\
CTX & $0.359 \pm 0.227$ & $0.365 \pm 0.287$ \\
HIPP & $0.707 \pm 0.391$ & $0.870 \pm 0.719$ \\
CB & $0.499 \pm 0.263$ & $0.685 \pm 0.564$ \\
STR & $0.482 \pm 0.322$ & $0.470 \pm 0.360$ \\
ROB & $0.519 \pm 0.451$ & $0.447 \pm 0.320$ \\
\hline
\end{tabular}


compatible with the desired pharmacological effect. We reassessed the PK parameters of doxycycline in mice with the main aim of providing the information needed to fine-tune preclinical studies in mouse models of neurodegenerative amyloidosis.

The peak plasma concentrations of doxycycline in the 7-week-old male C57BL76 mice, observed 1-2 hours after single intraperitoneal injections of 10 or $100 \mathrm{mg} / \mathrm{kg}$, were $2-10$ $\mu \mathrm{g} / \mathrm{ml}$, superimposable with those in humans taking the usual oral doses of 100-200 mg [1.7-5.9 $\mu \mathrm{g} / \mathrm{ml}$; (Saivin and Houin, 1988; Binh et al., 2009; Montagna et al., 2013)]. This is consistent with empirical allometric extrapolations (McCann and Ricaurte, 2001), following the principle of interspecies drug dose scaling, which suggests that a dose of $100 \mathrm{mg}$ in humans should correspond approximately to a dose of $15 \mathrm{mg} / \mathrm{kg}$ in mice. A nonsignificant increase in drug concentrations appeared 6 hours after the treatment with both 10 and $100 \mathrm{mg} / \mathrm{kg}$, in comparison with the concentrations measured after 4 hours. The presence of a second peak may be consistent with the enterohepatic recycling previously described for doxycycline in mice (Bocker at al., 1981) and tetracycline in rat (Adir, 1975); a second peak had also been reported in the plasma of patients treated with doxycycline (Fabre et al., 1966; Pedersen and Miller, 1980; Malmborg, 1984). We also found that the AUC for doxycycline in mice was proportional to the dose administered, at least within the $10-100 \mathrm{mg} / \mathrm{kg}$ range.

A slower $t_{1 / 2}$ was observed after treatment with $100 \mathrm{mg} / \mathrm{kg}$ than after $10 \mathrm{mg} / \mathrm{kg}$ (6.5 vs. 3.2 hours, respectively). Since this is accompanied by a less-than-proportional $\mathrm{C}_{\max }(10 \mathrm{vs} .2 \mu \mathrm{g} / \mathrm{ml}$ with 100 and $10 \mathrm{mg} / \mathrm{kg}$ ), we suggest that at the highest dose absorption became a limiting factor, a condition in which the terminal half-life also reflects rate and extent of absorption and not just the elimination process (Toutain and Bousquet-Mélou, 2004). However, plasma clearance was similar for the two doses.

There was a remarkable difference, however, in the half-time of elimination from plasma, which is 15-30 hours in humans (Saivin and Houin, 1988; Binh et al., 2009; Montagna et al., 2013) but significantly shorter in young mice [3-6 hours, in line with previous data (Schach won Wittenau et al., 1972; Bocker et al., 1981)]. Our old mice had an intermediate value of 11 hours (this is discussed below). These results have implications for treatment schedules, since a single daily dose may be justified in humans but not for mice. Doxycycline metabolism appeared negligible, confirming previous data (Bocker, 1983). In fact, plasma levels of $N$-demethyl-doxycycline, the only detectable metabolite, never exceed $5 \%$ of the levels of the parent drug; no metabolites were detected in brain samples of doxycycline-treated mice.

Mean maximum brain concentrations of 0.24 and $1.79 \mu \mathrm{g}$ doxycycline/g of brain were reached within 4-6 hours after 10 and $100 \mathrm{mg} / \mathrm{kg}$ doxycycline. Interestingly, the values in mice are comparable to those in autopsy samples from CJD patients chronically treated with $100 \mathrm{mg} /$ day: In individuals who received the last dose within 24 hours of death, levels were 0.6-3.0 $\mu \mathrm{g} / \mathrm{g}$ (Haik et al., 2014).

The present study describes for the first time the brain-toplasma ratio of doxycycline in mice, which was about 0.2 (calculated on the AUC values), after either 10 or $100 \mathrm{mg} / \mathrm{kg}$, in both young and old mice. Assuming that cerebral blood accounts for $2 \%$ of total blood (Edvinsson et al., 1973; Modak et al., 1978; Chugh et al., 2009), it follows that brain levels cannot be accounted for by the residual cerebral blood. This value is very similar to the cerebrospinal fluid/serum ratios in patients with neurosyphilis (Yim et al., 1985) or suspected tick-borne neuroborreliosis (Dotevall and Hagberg, 1989). Assuming a mean plasma protein binding of $80 \%-95 \%$ (Saivin and Houin, 1988; Riond and Riviere, 1989, 1990; Riond et al., 1990; Davis et al., 2006), the concentration gradient of doxycycline-i.e., the ratio of brain to free plasma concentration-is 1 to 2 with both doses, in agreement with that measured in rats (Colovic and Caccia, 2003), dogs (Barza et al., 1975), and humans (Yim et al., 1985; Dotevall and Hagberg, 1989).

The mean elimination half-times from the brain of young mice ( 3.9 and 6.5 hours, after 10 and $100 \mathrm{mg} / \mathrm{kg}$ ) were identical to those in plasma. This fast elimination suggests that no significant drug accumulation can be expected after repeated doses, even twice a day, as can be visually appreciated in the simulations shown in Figs. 2 and 3. Accordingly, the brain concentrations after 4-day treatment with 10 or $100 \mathrm{mg} / \mathrm{kg}$ were not significantly different from those after a single dose. These data show that maximal brain concentrations $\left(\mathrm{C}_{\max }\right)$ approaching $7 \mu \mathrm{M}$ on average can only be reached after $100 \mathrm{mg} / \mathrm{kg}$ doxycycline twice a day, whereas one dose a day gives up to $5 \mu \mathrm{M}$. After repeated doses of $10 \mathrm{mg} / \mathrm{kg}$, either once or twice a day, $\mathrm{C}_{\max }$ remains at $\sim 0.5 \mu \mathrm{M}$.

Elimination was slower from both plasma and brain of 20-month-old mice (11.1 and 15.4 hours, respectively); these data led us to estimate that brain concentrations up to $10 \mu \mathrm{M}$ might be reached after repeated doses (data not shown). Analysis of PK data also indicated greater exposure to the drug in older mice owing to the higher apparent volume of distribution as a consequence of the different weight (i.e., more adipose tissue), and this is a common observation for lipophilic drugs like doxycycline (Hanley et al., 2010).

Finally, doxycycline levels were similar in brain areas of 20-month-old WT and APP23 mice 24 hours after the fourth intraperitoneal injection, indicating no significant changes in $\mathrm{BBB}$ passage of the drug in $\mathrm{AD}$ mice.

The new details on doxycycline pharmacokinetics in the present study must be taken into account for fine tuning in vivo animal studies. In addition, the drug concentrations reached in the brain under specific treatment conditions may help identify the mechanism(s) of action of the central in vivo effects of doxycycline in mice. For example, it was recently shown (Balducci et al., 2018) that memory deficits in APP/PS1Tg mice are significantly rescued by single or repeated intraperitoneal doses of $10 \mathrm{mg} / \mathrm{kg}$ doxycycline, which results in brain concentrations always lower than $1 \mu \mathrm{M}$, i.e., lower than the concentrations required for antiaggregating effects in vitro $(\geq 10 \mu \mathrm{M})$ (Forloni et al., 2001, 2002; Cardoso et al., 2003; Giorgetti et al., 2011; Ward et al., 2011; De Luigi et al., 2015; Gonzalez-Lizarraga et al., 2017). This suggests that other properties of doxycycline might be at play, in accordance with the drug's pleiotropic activities (Stoilova et al., 2013). In fact, the positive cognitive effects of doxycycline in $\mathrm{AD}$ mice were not associated with any reduction of the $\mathrm{A} \beta$ plaque load, but there was a significant normalization effect on glial cells, whose activation in the $\mathrm{AD}$ mouse brain contributes to the memory impairment (Balducci et al., 2017), thus highlighting an important contribution of the drug's anti-inflammatory effects (Balducci et al., 2018). It has also been shown that the inhibitory effect of doxycycline on poly (ADP-ribose) 
polymerase-1 (PARP-1), involved in microglial activation, inflammation, and cell death (Kauppinen and Swanson, 2005), also induced by $\mathrm{A} \beta$ (Kauppinen et al., 2011), occurs at submicromolar concentrations (Alano et al., 2006), consistently with the concentrations actually measured in the brain of our mice.

\section{Acknowledgments}

We thank Dr. Diego Albani and Dr. Federica Fusco for providing APP23 and WT mice. We thank Dr. Pietro La Vitola for his help with treatment of the mice.

\section{Authorship Contributions}

Participated in research design: Lucchetti, Fracasso, Balducci, Forloni, Salmona, Gobbi.

Conducted experiments: Lucchetti, Fracasso, Passoni, Balducci.

Performed data analysis: Lucchetti, Fracasso, Gobbi.

Wrote or contributed to the writing of the manuscript: Lucchetti, Gobbi.

\section{References}

Adir J (1975) Enterohepatic circulation of tetracycline in rats. J Pharm Sci 64: $1847-1850$

Alano CC, Kauppinen TM, Valls AV, and Swanson RA (2006) Minocycline inhibits poly(ADP-ribose) polymerase-1 at nanomolar concentrations. Proc Natl Acad Sci USA 103:9685-9690.

Balducci C, Frasca A, Zotti M, La Vitola P, Mhillaj E, Grigoli E, Iacobellis M, Grandi F, Messa M, Colombo L, et al. (2017) Toll-like receptor 4-dependent glial cell activation mediates the impairment in memory establishment induced by $\beta$-amyloid oligomers in an acute mouse model of Alzheimer's disease. Brain Behav Immun 60 188-197.

Balducci C, Santamaria G, La Vitola P, Brandi E, Grandi F, Viscomi AR, Beeg M, Gobbi M, Salmona M, Ottonello S, et al. (2018) Doxycycline counteracts neuroinflammation restoring memory in Alzheimer's disease mouse models. Neurobiol Aging 70:128-139.

Barza M, Brown RB, Shanks C, Gamble C, and Weinstein L (1975) Relation between lipophilicity and pharmacological behavior of minocycline, doxycycline, tetracycline, and oxytetracycline in dogs. Antimicrob Agents Chemother 8: 713-720.

Binh VQ, Chinh NT, Thanh NX, Cuong BT, Quang NN, Dai B, Travers T, and Edstein MD (2009) Sex affects the steady-state pharmacokinetics of primaquine but not doxycycline in healthy subjects. Am J Trop Med Hyg 81: $747-753$.

Böcker R (1983) Analysis and quantitation of a metabolite of doxycycline in mice, rats, and humans by high-performance liquid chromatography. $J$ Chromatogr $A$ 274:255-262.

Böcker R, Estler CJ, Maywald M, and Weber D (1981) Comparison of distribution of doxycycline in mice after oral and intravenous application measured by a high-performance liquid chromatographic method. Arzneimittelforschung 31: $2116-2117$

Boxenbaum H (1982) Interspecies scaling, allometry, physiological time, and the ground plan of pharmacokinetics. $J$ Pharmacokinet Biopharm 10 201-227.

Cardoso I, Merlini G, and Saraiva MJ (2003) 4'-iodo-4'-deoxydoxorubicin and tetracyclines disrupt transthyretin amyloid fibrils in vitro producing noncytotoxic species: screening for TTR fibril disrupters. FASEB $J$ 17:803-809.

Cardoso I and Saraiva MJ (2006) Doxycycline disrupts transthyretin amyloid: evidence from studies in a FAP transgenic mice model. FASEB $J \mathbf{2 0}$ 234-239.

Chiti F and Dobson CM (2006) Protein misfolding, functional amyloid, and human disease. Annu Rev Biochem 75:333-366.

Chopra I and Roberts M (2001) Tetracycline antibiotics: mode of action, applications, molecular biology, and epidemiology of bacterial resistance. Microbiol Mol Biol Rev 65:232-260.

Chugh BP, Lerch JP, Yu LX, Pienkowski M, Harrison RV, Henkelman RM, and Sled JG (2009) Measurement of cerebral blood volume in mouse brain regions using micro-computed tomography. Neuroimage 47:1312-1318.

Colovic M and Caccia S (2003) Liquid chromatographic determination of minocycline in brain-to-plasma distribution studies in the rat. J Chromatogr B Analyt Technol Biomed Life Sci 791:337-343.

Cunha BA, Sibley CM, and Ristuccia AM (1982) Doxycycline. Ther Drug Monit 4: $115-135$

Davis JL, Salmon JH, and Papich MG (2006) Pharmacokinetics and tissue distribution of doxycycline after oral administration of single and multiple doses in horses. Am J Vet Res 67:310-316.

De Luigi A, Colombo L, Diomede L, Capobianco R, Mangieri M, Miccolo C, Limido L, Forloni G, Tagliavini F, and Salmona M (2008) The efficacy of tetracyclines in peripheral and intracerebral prion infection. PLoS One 3: e1888.

De Luigi A, Mariani A, De Paola M, Re Depaolini A, Colombo L, Russo L, Rondelli V, Brocca P, Adler-Abramovich L, Gazit E, et al. (2015) Doxycycline hinders phenylalanine fibril assemblies revealing a potential novel therapeutic approach in phenylketonuria. Sci Rep 5:15902.
Diomede L, Cassata G, Fiordaliso F, Salio M, Ami D, Natalello A, Doglia SM, De Luigi A, and Salmona M (2010) Tetracycline and its analogues protect Caenorhabditis elegans from $\beta$ amyloid-induced toxicity by targeting oligomers. Neurobiol Dis 40:424-431.

Dotevall L and Hagberg L (1989) Penetration of doxycycline into cerebrospinal fluid in patients treated for suspected Lyme neuroborreliosis. Antimicrob Agents Chemother 33:1078-1080.

Edvinsson L, Nielsen KC, and Owman C (1973) Circadian rhythm in cerebral blood volume of mouse. Experientia 29:432-433.

Fabre J, Pitton JS, and Kunz JP (1966) Distribution and excretion of doxycycline in man. Chemotherapy 11:73-85.

Forloni G, Colombo L, Girola L, Tagliavini F, and Salmona M (2001) Antiamyloidogenic activity of tetracyclines: studies in vitro. FEBS Lett 487: 404-407.

Forloni G, Iussich S, Awan T, Colombo L, Angeretti N, Girola L, Bertani I, Poli G, Caramelli M, Grazia Bruzzone M, et al. (2002) Tetracyclines affect prion infectivity. Proc Natl Acad Sci USA 99:10849-10854.

Forloni G, Tettamanti M, Lucca U, Albanese Y, Quaglio E, Chiesa R, Erbetta A, Villani F, Redaelli V, Tagliavini F, et al. (2015) Preventive study in subjects at risk of fatal familial insomnia: innovative approach to rare diseases. Prion 9: 75-79.

Giorgetti S, Raimondi S, Pagano K, Relini A, Bucciantini M, Corazza A, Fogolari F, Codutti L, Salmona M, Mangione P, et al. (2011) Effect of tetracyclines on the dynamics of formation and destructuration of beta2-microglobulin amyloid fibrils. J Biol Chem 286:2121-2131.

González-Lizárraga F, Socías SB, Ávila CL, Torres-Bugeau CM, Barbosa LR, Binolfi A, Sepúlveda-Díaz JE, Del-Bel E, Fernandez CO, Papy-Garcia D, et al. (2017) Repurposing doxycycline for synucleinopathies: remodelling of $\alpha$-synuclein oligomers towards non-toxic parallel beta-sheet structured species. Sci Rep 7:41755.

Griffin MO, Fricovsky E, Ceballos G, and Villarreal F (2010) Tetracyclines: a pleitropic family of compounds with promising therapeutic properties. Review of the literature. Am J Physiol Cell Physiol 299:C539-C548.

Haïk S, Marcon G, Mallet A, Tettamanti M, Welaratne A, Giaccone G, Azimi S, Pietrini V, Fabreguettes JR, Imperiale D, et al. (2014) Doxycycline in CreutzfeldtJakob disease: a phase 2, randomised, double-blind, placebo-controlled trial. Lancet Neurol 13:150-158.

Hanley MJ, Abernethy DR, and Greenblatt DJ (2010) Effect of obesity on the pharmacokinetics of drugs in humans. Clin Pharmacokinet 49:71-87.

Kauppinen TM, Suh SW, Higashi Y, Berman AE, Escartin C, Won SJ, Wang C, Cho SH, Gan L, and Swanson RA (2011) Poly(ADP-ribose)polymerase-1 modulates microglial responses to amyloid $\beta$. J Neuroinflammation 8:152.

Kauppinen TM and Swanson RA (2005) Poly(ADP-ribose) polymerase-1 promotes microglial activation, proliferation, and matrix metalloproteinase-9-mediated neuron death. J Immunol 174:2288-2296.

Loeb MB, Molloy DW, Smieja M, Standish T, Goldsmith CH, Mahony J, Smith S, Borrie M, Decoteau E, Davidson W, et al. (2004) A randomized, controlled trial of doxycycline and rifampin for patients with Alzheimer's disease. J Am Geriatr Soc 52:381-387.

Malmborg AS (1984) Bioavailability of doxycycline monohydrate. A comparison with equivalent doses of doxycycline hydrochloride. Chemotherapy $\mathbf{3 0}$ : $76-80$

McCann UD and Ricaurte GA (2001) Caveat emptor: editors beware. Neuropsychopharmacology 24:333-336.

Modak AT, Stavinoha WB, Frazer JW, and Deam AP (1978) Estimation of blood content in the mouse brain by measurement of iron. $J$ Pharmacol Methods 1: 247-253.

Molloy DW, Standish TI, Zhou Q, and Guyatt G; DARAD Study Group (2013) A multicenter, blinded, randomized, factorial controlled trial of doxycycline and rifampin for treatment of Alzheimer's disease: the DARAD trial. Int J Geriatr Psychiatry 28:463-470.

Montagna G, Cazzulani B, Obici L, Uggetti C, Giorgetti S, Porcari R, Ruggiero R, Mangione PP, Brambilla M, Lucchetti J, et al. (2013) Benefit of doxycycline treatment on articular disability caused by dialysis related amyloidosis. Amyloid 20:173-178.

Obici L, Cortese A, Lozza A, Lucchetti J, Gobbi M, Palladini G, Perlini S, Saraiva MJ, and Merlini G (2012) Doxycycline plus tauroursodeoxycholic acid for transthyretin amyloidosis: a phase II study. Amyloid 19 (Suppl 1):34-36.

Pedersen PV and Miller R (1980) Pharmacokinetics of doxycycline reabsorption. $J$ Pharm Sci 69:204-207.

Riond JL and Riviere JE (1989) Doxycycline binding to plasma albumin of several species. $J$ Vet Pharmacol Ther 12:253-260.

Riond JL and Riviere JE (1990) Pharmacokinetics and metabolic inertness of doxycycline in young pigs. Am $J$ Vet Res 51:1271-1275.

Riond JL, Vaden SL, and Riviere JE (1990) Comparative pharmacokinetics of doxycycline in cats and dogs. $J$ Vet Pharmacol Ther 13:415-424.

Rowland M and Tozer TN (2011) Clinical Pharmacokinetics and Pharmacodynamics: Concepts and Applications, 4th ed, Lippincott Williams \& Wilkins, Philadelphia.

Saivin S and Houin G (1988) Clinical pharmacokinetics of doxycycline and minocycline. Clin Pharmacokinet 15:355-366.

Schach won Wittenau M, Schachaavonwittenau M, Twomey TM, and Swindell AC (1972) The disposition of doxycycline by the rat. Chemotherapy 17: $26-39$

Stoilova T, Colombo L, Forloni G, Tagliavini F, and Salmona M (2013) A new face for old antibiotics: tetracyclines in treatment of amyloidoses. J Med Chem 56: 5987-6006.

Toutain PL and Bousquet-Mélou A (2004) Plasma terminal half-life. $J$ Vet Pharmacol Ther 27:427-439. 
Varges D, Manthey H, Heinemann U, Ponto C, Schmitz M, Schulz-Schaeffer WJ, Krasnianski A, Breithaupt M, Fincke F, Kramer K, et al. (2017) Doxycycline in early CJD: a double-blinded randomised phase II and observational study. $J$ Neurol Neurosurg Psychiatry 88:119-125.

Ward JE, Ren R, Toraldo G, Soohoo P, Guan J, O'Hara C, Jasuja R, TrinkausRandall V, Liao R, Connors LH, et al. (2011) Doxycycline reduces fibril formation in a transgenic mouse model of $\mathrm{AL}$ amyloidosis. Blood 118 $6610-6617$.

Wechalekar AD and Whelan C (2017) Encouraging impact of doxycycline on early mortality in cardiac light chain (AL) amyloidosis. Blood Cancer $J$ 7: e546.

Yim CW, Flynn NM, and Fitzgerald FT (1985) Penetration of oral doxycycline into the cerebrospinal fluid of patients with latent or neurosyphilis. Antimicrob Agents Chemother 28:347-348.
Zhang Y, Huo M, Zhou J, and Xie S (2010) PKSolver: an add-in program for pharmacokinetic and pharmacodynamic data analysis in Microsoft Excel. Comput Methods Programs Biomed 99:306-314

Address correspondence to: Dr. Jacopo Lucchetti, Laboratory of Pharmacodynamics and Pharmacokinetics, Department of Molecular Biochemistry and Pharmacology, Instituto di Ricerche Farmacologiche Mario Negri IRCCS via La Masa 19, 20156 Milan, Italy. E-mail: jacopo.lucchetti@marionegri.it; or Dr. Marco Gobbi, Laboratory of Pharmacodynamics and Pharmacokinetics, Department of Molecular Biochemistry and Pharmacology, Instituto di Ricerche Farmacologiche Mario Negri IRCCS, via La Masa 19, 20156 Milan, Italy. E-mail: marco.gobbi@marionegri.it 